\title{
Solidification of High Organic Matter Content Sludge by Cement, Lime and Metakaolin
}

\author{
Ke Rui', Wang Hongxing ${ }^{* 2}$, Tan Yunzhi', Wang Lehua² \\ 1 The Institute of Problematic Soils Mechanics, \\ China Three Gorges University, Yichang, 443002,China \\ 2 Hubei Key Laboratory of Disaster Prevention and Mitigation, \\ China Three Gorges University, Yichang, 443002, China \\ * Corresponding author, e-mail: wanghongxinglih@126.com
}

Received: 24 March 2018, Accepted: 04 October 2018, Published online: 29 October 2018

\begin{abstract}
Based on orthogonal experimental design, the key solidification controlling technology of Solidified/Stabilized (S/S) sludge with high total organic content (TOC) by cement, lime and metakaolin was explored by macroscopic tests, chemical components measurements and microscopic analysis. The macroscopic tests show that, the permeability coefficient is mainly affected by initial water content and lime content, and the unconfined compression strength is mainly affected by cement content and lime content. The chemical components measurements show that, the solidification effect of S/S sludge with high TOC is controlled by organic matter consumption, and organic matter consumption is determined by the alkaline environment from the cement and lime hydration reactions, which is mainly affect by the initial water content and lime-metakaolin content ratio. The microscopic analysis results show that, lime consumes parts of organic matter while excess lime produces weak $\mathrm{Ca}(\mathrm{OH})_{2}$ crystal fluffy sheet structure, matakaolin produces pozzolanic reactions with cement and lime instead of soil particles, and consumes the weak $\mathrm{Ca}(\mathrm{OH})_{2}$ crystal fluffy sheet structure produced by superfluous lime. The research has confirmed key controlling points of S/S sludge in case of high TOC, which will provide theoretical guidance and technical support for S/S sludge promotion with high TOC.
\end{abstract}

Keywords

solidified/stabilized sludge, high total organic content, organic matter consumption, key controlling technology

\section{Introduction}

The sludge deposited in waterways such as urban ditches, rivers, lakes and seas, hinders navigation, worsens water quality and thus requires regular dredging [1]. Dredged sludge exposed to the atmosphere in yards produces pollution to the surrounding water and soil, occupies a large amount of land resources, and raises dredging project cost at the same time [2-8]. Solidification/Stabilization (S/S) technology through cement and other solidification agents, transfers dredged sludge into engineering fillers (S/S sludge), so as to promote the large-scale utilization of dredged sludge, which has many social and economic values, such as environmental protection, cost saving and so on. The engineering applicability of $\mathrm{S} / \mathrm{S}$ sludge was improved owing to past researches about the macroscopic performance, chemical components and microscopic structures [9-11]. However, during the formation of sludge, a large amount of organic matter was formed by the decay of animal and plant residues [12-16]. On one hand, the organic matter wraps the clay particles and hinders the reaction between the solidification agents and the clay particles. On the other hand, since the organic matter is acidic [17-19], it will produce neutralization reaction with alkaline substances produced by solidification agent hydration reaction, which will reduce the $\mathrm{pH}$ of the solution, and then hinders the hydration reaction of solidification agents [20-22]. So for S/S sludge with high total organic content (TOC), the solidification effect is often poor.

In order to improve the solidification effect of $\mathrm{S} / \mathrm{S}$ sludge with high TOC, researchers tried lots of methods to explore the construction technology improvement and the solidification agents' optimization. In the study of construction technology improvement, the research work mainly reduced the porosity by reducing the initial water content of sludge. This method can achieve better 
Table 1 Basic properties of dredge silt

\begin{tabular}{ccccccccc}
\hline $\mathrm{W} / \%$ & $\mathrm{~W}_{\mathrm{L}} / \%$ & $\mathrm{~W}_{\mathrm{P}} / \%$ & $\mathrm{I}_{\mathrm{p}}$ & $\mathrm{I}_{\mathrm{L}}$ & $\begin{array}{c}\text { Specific } \\
\text { gravity }\end{array}$ & TOC/\%o & $\mathrm{pH}$ \\
\hline 178 & 73 & 34 & 39 & 3.69 & 2.3 & 43.81 & 7.32 \\
\hline \multicolumn{10}{c}{ Table 2} \\
\hline \multicolumn{10}{c}{ Chemical compositions of cement, lime and metakaolin $/ \%$} \\
\hline $\mathrm{C}$ & 23.35 & 4.03 & 7.92 & 55.76 & 2.09 & 2.82 & 0.31 & 0.22 \\
$\mathrm{~L}$ & 6.8 & 1.5 & 2.3 & 51.4 & 1.7 & - & - & - \\
$\mathrm{M}$ & 53.5 & 0.3 & 43.0 & 0.5 & 0.3 & - & 0.06 & 0.001 \\
\hline
\end{tabular}

solidification effect for dredge sludge with low TOC, but there was always no significant improvement when TOC is high. In the study of the solidification agents' optimization, cement, lime and metakaolin are the three primary agents that have been explored. Cement is a traditional solidification agent, which can produce strong Calcium Silicate Hydrate (CSH) through hydration reaction, ion exchange, granulation reaction, pozzolanic reaction and carbonization reaction [23-25]. The alkaline substances loss by neutralization reaction of organic matter can be compensated by cement content increase. This method can effectively improve the solidification effect of sludge with high TOC, while the cost is higher. In contrast to cement, lime is less costly, can quickly provide a large amount of alkaline substances such as calcium hydroxide $\left(\mathrm{Ca}(\mathrm{OH})_{2}\right)$ for the neutralization consumption of organic matter, thereby reduces the cement reaction products loss induced by organic matter [22, 26-29]. This method can improve the solidification effect of sludge with high TOC sometimes, but the solidification effect is often unstable, and sometimes there is even a negative effect [30-32]. Metakaolin is widely distributed, low cost, and widely used in concrete, geo-polymers and other civil engineering materials, which can quickly reacts with cement, lime and other alkaline materials to form a three-dimensional grid solid structure, so as to reduce obstruction of the organic matter in a certain extent [33, 34]. But unfortunately, the solidification effect is not stable either [35, 36]. In a word, the existing construction process improvement and the solidification agents' optimization can promote the $\mathrm{S} / \mathrm{S}$ sludge solidification effect in a certain extent in case of high TOC, but so far, there is not a clear and stable method which is economical and reasonable, which has confused engineering technicians for a long time.

Therefore, this paper has designed an orthogonal test [37, 38] with 4 factors 3 levels to explore the solidification technology for sludge with high TOC, taking the initial moisture content, cement content, lime content, and metakaolin content as the influence factors. Macroscopic tests, chemical components measurements and microscopic analysis are conducted to obtain the corresponding parameters for $\mathrm{S} / \mathrm{S}$ sludge solidification effect evaluation. The key controlling technology of S/S sludge with high TOC is supposed to be figured out based on the above work, which will promote the applicability of S/S sludge in engineering.

\section{Raw materials and test program}

\subsection{Raw materials}

Dredged sludge was picked up from a dredging site in Hubei Province in China. Fresh sludge is dark, plastic flow state, delicate texture, with lots of organic matter from animal and plant residues. The sludge $\mathrm{pH}$ value is $7.32 \sim 8.1$, measured by digital $\mathrm{pH}$ meter test. The clay content is $81.3 \%$, gained by sieving method $(>=0.075$ $\mathrm{mm})$ and hydrometer method $(<0.075 \mathrm{~mm})$. The TOC is $43.81 \%$, tested from potassium dichromate oxidation titration. $\mathrm{SiO}_{2}$ and $\mathrm{NaAlSi}_{3} \mathrm{O}_{8}$ account a huge proportion of the sludge composition, and $\mathrm{CaCO}_{3}, \mathrm{CaMg}\left(\mathrm{CO}_{3}\right)_{2}$ and $(\mathrm{Na}$, $\mathrm{K})\left(\mathrm{Si}_{3} \mathrm{Al}\right) \mathrm{O}_{8}$ are also contained, gained by XRD analysis. The sludge basic physical properties are shown in Table 1.

The chemical compositions of solidification agents, such as ordinary Portland cement (C), lime (L) and metakaolin (M), purchased by commercial means, are shown in Table 2.

\subsection{Sample preparation}

The specimens for permeability coefficient (PC) test were prepared through the cutting ring with diameter of 61.8 $\mathrm{mm}$ and height of $20 \mathrm{~mm}$. The unconfined compression strength (UCS) test specimens were prepared by the cylinder mold with internal diameter of $35 \mathrm{~mm}$ and height of $70 \mathrm{~mm}$. The sample preparation process was as follows: reduce the original sludge water content to the expected value $(80 \%, 100 \%, 120 \%)$ by preloading device, add solidification agents (cement, lime, metakaolin) to sludge according to the wet weight ratio, mix the solidification agents and sludge evenly with a high speed mixer, fill the sample in the mold by 3 times in 30 min with loading 1/3 each time, compact the sample in vibrating table until no bubble emitting, place the sample and mold together in the constant temperature humidity chamber(temperature is $25^{\circ} \mathrm{C}$, humidity is $95 \%$ ) for 3 days, withdraw the sample from the mold and lay the sample in the chamber right along. The specimens prepared for microscopic tests were cut from cylinder specimens of UCS test according to the different test method requirements. 
Table 3 Factors and levels for the orthogonal test program

\begin{tabular}{lcc}
\hline Factors & Abbr. & Levels \\
\hline Initial water content & Wc & $\mathrm{W} 1=80 \%, \mathrm{~W} 2=100 \%, \mathrm{~W} 3=120 \%$ \\
Cement content & $\mathrm{Cc}$ & $\mathrm{C} 1=10 \%, \mathrm{C} 2=12 \%, \mathrm{C} 3=15 \%$ \\
Lime content & Lc & $\mathrm{L} 1=0 \%, \mathrm{~L} 2=2 \%, \mathrm{~L} 3=3 \%$ \\
Metakaolin content & $\mathrm{Mc}$ & $\mathrm{M} 1=0 \%, \mathrm{M} 2=1 \%, \mathrm{M} 3=2 \%$ \\
\hline
\end{tabular}

\subsection{Test program}

The orthogonal test with 4 factors 3 levels (Table 3) was designed to test the macroscopic parameters such as PC and UCS and chemical components such as $\mathrm{pH}$, electrical conductivity (EC), $\mathrm{Ca}^{+}$concentration and TOC, for sensitivity analysis, as shown in Table 4 . In order to enhance the reliability of the test data, 3 groups of parallel tests were carried out for each working condition, the unreliable data were eliminated and the average value was used.

\section{Test methods}

\subsection{Macroscopic test methods}

The macroscopic tests in this paper mainly include PC test and UCS test. S/S sludge belongs to fine grained soil, so the variable head method was used to carry out the permeability test to obtain the PC. The strain control universal testing machine was used to test the UCS of S/S sludge.

\subsection{Chemical components measurements}

(1) $\mathrm{pH}, \mathrm{EC}$ and $\mathrm{Ca}^{2+}$ concentration measurements

METTLER TOLEDO multi parameter measuring instrument was used to determine the $\mathrm{pH}, \mathrm{EC}$ and $\mathrm{Ca}^{2+}$ concentration of $\mathrm{S} / \mathrm{S}$ sludge. 10 gram of specimen through the $0.25 \mathrm{~mm}$ soil sieve was added with $50 \mathrm{ml}$ distilled water, stirred, and the supernatant was extracted for measuring.

\section{(2) TOC measurement}

TOC in S/S sludge was measured by potassium dichromate oxidation titration method: measure the water content $(W)$ of $\mathrm{S} / \mathrm{S}$ sludge sample, put the sample into the boiling tube, add potassium dichromate-sulphuric acid solution, put the boiling tube in graphite digestion instrument and heat for $5 \mathrm{~min}$ at $185^{\circ} \mathrm{C}$ high temperature, take out the tube and use $50 \mathrm{ml}$ distilled water to wash away the cooking fluid and soil residue, wash the liquid into the triangle bottle, add 3 drops of phenanthroline indicator to titrate with standard solution of ammonium ferrous sulphate, record the volume $V$ when the solution colour changes from orange, to yellow -blue, to green - brown, to red. The blank test must be done at the same time for each batch analysis, record the volume $V_{0}$.

The experimental results are obtained by the following formula as shown in Eq. (1).

$$
T O C=\frac{C \times\left(V_{0}-V\right) \times(1+0.01 W) \times 0.003 \times 1.724 \times 1.1}{M} \times 100
$$

Note: $C$-concentration of potassium dichromate-sulfuric acid solution

$V_{0}$ - blank sample consumption

$V$ - sample consumption

$W$ - the moisture content of sample

$M$ - sample quality

\subsection{Microscopic test}

Plate the sample with gold after lyophilisation treatment, use Zeiss Ultra Plus SEM to analyze the micro structure with magnification of 5000, to observe the internal structure of the $\mathrm{S} / \mathrm{S}$ sludge in different matching, and to determine the main components of the substance.

Table 4 The orthogonal test program

\begin{tabular}{|c|c|c|c|c|c|}
\hline \multirow{2}{*}{ No. } & \multicolumn{4}{|c|}{ Factors } & \multirow{2}{*}{$\mathrm{y}$} \\
\hline & Wc & $\mathrm{Cc}$ & $\mathrm{Lc}$ & $\mathrm{Mc}$ & \\
\hline 1 & W1 & $\mathrm{C} 1$ & $\mathrm{~L} 1$ & M1 & y1 \\
\hline 2 & W1 & $\mathrm{C} 2$ & L2 & M2 & y2 \\
\hline 3 & W1 & $\mathrm{C} 3$ & L3 & M3 & y3 \\
\hline 4 & W2 & $\mathrm{C} 1$ & L2 & M3 & y4 \\
\hline 5 & W2 & $\mathrm{C} 2$ & L3 & M1 & y5 \\
\hline 6 & W2 & $\mathrm{C} 3$ & L1 & M2 & y6 \\
\hline 7 & W3 & $\mathrm{C} 1$ & L3 & M2 & y7 \\
\hline 8 & W3 & $\mathrm{C} 2$ & $\mathrm{~L} 1$ & M3 & y8 \\
\hline 9 & W3 & $\mathrm{C} 3$ & L2 & M1 & y9 \\
\hline $\mathrm{I}_{1}$ & $(y 1+y 2+y 3) / 3$ & $(y 1+y 4+y 7) / 3$ & $(y 1+y 6+y 8) / 3$ & $(y 1+y 5+y 9) / 3$ & \\
\hline $\mathrm{I}_{2}$ & $(y 4+y 5+y 6) / 3$ & $(y 2+y 5+y 8) / 3$ & $(y 2+y 4+y 9) / 3$ & $(y 2+y 6+y 7) / 3$ & $\mathrm{Y}=\left(\sum \mathrm{yi}\right) / \mathrm{S}$ \\
\hline $\mathrm{I}_{3}$ & $(y 7+y 8+y 9) / 3$ & $(y 3+y 6+y 9) / 3$ & $(y 3+y 5+y 7) / 3$ & $(y 3+y 4+y 8) / 3$ & \\
\hline
\end{tabular}


Table 5 The macroscopic test results

\begin{tabular}{lllllll}
\hline \multirow{2}{*}{ No. } & \multicolumn{4}{c}{ Factors } & & \\
& Wc & Cc & Lc & Mc & PC $/\left(10^{-3} / \mathrm{d}\right)$ & UCS $/ \mathrm{kPa}$ \\
\hline 1 & W1 & C1 & L1 & M1 & 0.44 & 280.0 \\
2 & W1 & C2 & L2 & M2 & 1.20 & 1173.8 \\
3 & W1 & C3 & L3 & M3 & 1.13 & 1170.0 \\
4 & W2 & C1 & L2 & M3 & 1.74 & 658.1 \\
5 & W2 & C2 & L3 & M1 & 2.18 & 308.1 \\
6 & W2 & C3 & L1 & M2 & 1.13 & 764.4 \\
7 & W3 & C1 & L3 & M2 & 1.25 & 409.4 \\
8 & W3 & C2 & L1 & M3 & 0.091 & 1199.4 \\
9 & W3 & C3 & L2 & M1 & 1.71 & 818.1 \\
\hline
\end{tabular}

Table 6 Range analysis for PC $/\left(10^{-3} \mathrm{~m} / \mathrm{d}\right)$

\begin{tabular}{|c|c|c|c|c|c|}
\hline \multirow{2}{*}{ Factors } & \multicolumn{3}{|c|}{ Levels } & \multirow{2}{*}{$\mathrm{R}$} & \multirow{2}{*}{$\mathrm{T}$} \\
\hline & $\delta 1$ & $\delta 2$ & $\delta 3$ & & \\
\hline \multirow[t]{2}{*}{ Wc } & -0.28 & 0.47 & -0.19 & 0.47 & 0.76 \\
\hline & & & & -0.28 & \\
\hline \multirow[t]{2}{*}{$\mathrm{Cc}$} & -0.066 & -0.049 & 0.12 & 0.12 & 0.18 \\
\hline & & & & -0.066 & \\
\hline \multirow[t]{2}{*}{$\mathrm{Lc}$} & -0.66 & 0.34 & 0.31 & 0.34 & 1.00 \\
\hline & & & & -0.66 & \\
\hline \multirow[t]{2}{*}{$\mathrm{Mc}$} & 0.23 & -0.015 & 0.22 & 0.23 & 0.25 \\
\hline & & & & -0.015 & \\
\hline
\end{tabular}

Table 7 Term explanations for range analysis

\begin{tabular}{ccc}
\hline Variable & Expression & Meaning \\
\hline$\delta 1$ & $\delta 1=\mathrm{I} 1-\mathrm{Y}$ & $\begin{array}{c}\text { Difference between average } \\
\text { value of each level and three total } \\
\text { levels }\end{array}$ \\
$\delta 2$ & $\delta 2=\mathrm{I} 2-\mathrm{Y}$ & Maximum and minimum values \\
$\delta 3$ & $\delta 3=\mathrm{I} 3-\mathrm{Y}$ & of $\delta 1, \delta 2, \delta 3$ \\
$\mathrm{R}$ & $\operatorname{Max}(\delta 1, \delta 2, \delta 3)$ & Range value \\
& $\operatorname{Min}(\delta 1, \delta 2, \delta 3)$ & \\
$\mathrm{T}$ & $\operatorname{Max}(\delta 1, \delta 2, \delta 3)$ & \\
\hline
\end{tabular}

\section{Macroscopic test results}

According to orthogonal test (L9 $\left(3^{4}\right)$ ), the PC test results and UCS test results are carried out in Table 5. Regardless of the solidification effect being evaluated by the PC or $\mathrm{UCS}$, the optimal match is $W 3 C 2 L 1 M 3$. So, there is close correlation between $\mathrm{PC}$ and UCS for $\mathrm{S} / \mathrm{S}$ sludge. In order to further clarify the sensitivity of $\mathrm{S} / \mathrm{S}$ sludge to the above influence factors, the range analysis and variance analysis of PC and UCS are carried out respectively.

\subsection{PC analysis}

Range analysis for PC is carried out as shown in Table 6, the term explanations for the range analysis in Table 6 are shown in Table 7. In Table 7, $T$ is the absolute difference
Table 8 Variance analysis for PC

\begin{tabular}{lcccc}
\hline Factors & SS & DOF & MSD & F \\
\hline Wc & 3.2880 & 2 & 1.6440 & 4.3550 \\
Cc & 2.3256 & 2 & 1.1628 & 3.0802 \\
Lc & 4.2061 & 2 & 2.103 & 5.5710 \\
Mc & 2.5750 & 2 & 1.2875 & 3.4106 \\
Error & 6.7950 & 18 & 0.3775 & \\
\hline
\end{tabular}

Table 9 Term explanations for variance analysis

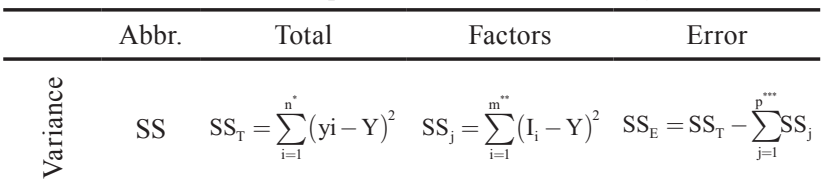

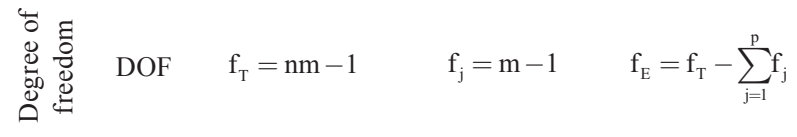

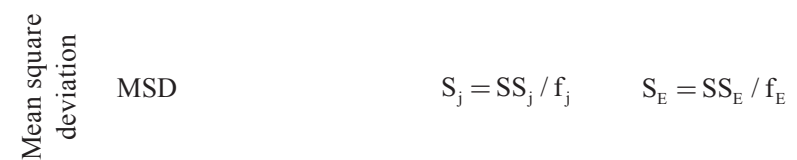
项总 $F \quad F_{j}=S_{j} / S_{E}$

$*_{\mathrm{n}}$ is the test numbers.

**m $\mathrm{m}$ is the level numbers for every factor.

$* * * \mathrm{p}$ is the factor numbers.

between the corresponding maximum value and minimum value in $R$. The larger the value of $T$, the greater the impact of the factor acts on the test results.

From Table 6, the range analysis results show that, the sensitivity levels sequence (SLS) for PC is $T_{L c}>T_{W_{c}}>T_{M c}>$ $T_{C c}\left(1.00 * 10^{-3}>0.76^{*} 10^{-3}>0.25^{*} 10^{-3}>0.18^{*} 10^{-3}\right)$. Among them, the influence of $L c$ and $W c$ is relatively close, while the influence of $C c$ and $M c$ is relatively close.

The optimum match and the sensitivity levels in the range analysis are obtained by a small amount of calculations. This method ignores the inevitable errors in the test process $[39,40]$. And the variance analysis and significance check to judge the significance according to the $F$ distribution function, will just make up for this deficiency. The variance analysis for PC is shown in Table 8, and the term explanations for variance analysis in Table 8, are shown in Table 9.

Based on Table 8, $F$ function value is compared with $F_{0.05}\left(f=2, f_{\text {total }}=26\right)=3.37$ at the check level of 0.05 , to determine the significance of each factor on the test results. When $F>F_{0.05}$, the influence is significant, vice versa. The larger the value of $F$, the greater the impact of the factor acts on the test results. 
Table 10 Range analysis for UCS $/ \mathrm{kPa}$

\begin{tabular}{|c|c|c|c|c|c|}
\hline \multirow{2}{*}{ Factors } & \multicolumn{3}{|c|}{ Levels } & \multirow{2}{*}{$\mathrm{R}$} & \multirow{2}{*}{$\mathrm{T}$} \\
\hline & $\delta 1$ & $\delta 2$ & $\delta 3$ & & \\
\hline \multirow[t]{2}{*}{ Wc } & 210.5 & -87.2 & -123.3 & 210.5 & 333.8 \\
\hline & & & & -123.3 & \\
\hline \multirow[t]{2}{*}{$\mathrm{Cc}$} & -214.9 & 410.7 & 253.4 & 410.7 & 625.6 \\
\hline & & & & -214.9 & \\
\hline \multirow[t]{2}{*}{$\mathrm{Lc}$} & -184.3 & 219.2 & -34.9 & 219.2 & 403.5 \\
\hline & & & & -184.3 & \\
\hline \multirow[t]{2}{*}{$\mathrm{Mc}$} & -195.4 & 118.4 & 76.9 & 118.4 & 313.8 \\
\hline & & & & -195.4 & \\
\hline
\end{tabular}

Table11 Variance analysis and significance test for UCS

\begin{tabular}{lcccc}
\hline Factors & SS & DOF & MSD & F \\
\hline M & 201350.9 & 2 & 100675.45 & 3.6134 \\
Cc & 837204.2 & 2 & 418602.1 & 15.0246 \\
Lc & 249699.4 & 2 & 124849.7 & 4.4811 \\
Mc & 174340 & 2 & 87170 & 3.1287 \\
Error & 501497.8 & 18 & 27860.9888 & \\
\hline
\end{tabular}

By comparison, $F_{L c}>F_{W c}>F_{M c}$ are all bigger than 3.37, and $F_{L c}$ is the biggest which presents the most significant influence of Lc on PC. While the $F_{C c}$ is less than 3.37, so that $C c$ has no significant influence on $\mathrm{PC}$. The result is consistent with the above range analysis, which has verified the applicability of range analysis.

Thus, S/S sludge PC is mainly affected by $L c$ and $W c$. Therefore, when PC is used to evaluate the solidification effect of S/S sludge mainly, the control of $L c$ and $W c$ should be considered emphatically.

\subsection{UCS analysis}

The range analysis results for UCS are shown in Table 10. The SLS is $T_{C c}>T_{L c}>T_{W c}>T_{M c}(625.6>403.5>333.8>$ 313.8). Among them, $T_{C c}$ and $T_{L c}$ are larger, while $T_{W c}$ and $T_{M c}$ are close and smaller.

The UCS variance analysis is shown in Table 11. By comparison, $F_{C c}>F_{L c}>F_{W c}$ are all bigger than 3.37, and $F_{C c}$ is the biggest which presents the most significant influence of $C c$ on UCS. While $F_{M c}$ is less than 3.37, so that $M c$ has no significant influence on UCS. The result is consistent with the above range analysis, which has verified the applicability of range analysis.

Thus, S/S sludge UCS is mainly affected by $C c$ and $L c$. Therefore, when UCS is used to evaluate the solidification effect of S/S sludge mainly, the control of $C c$ and $L c$ should be considered emphatically.
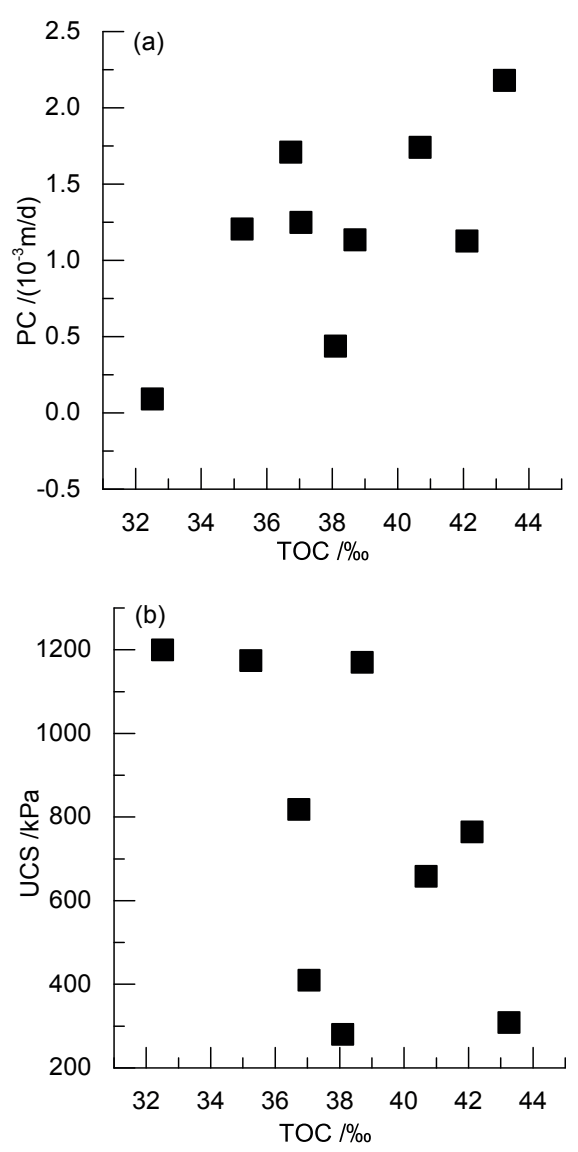

Fig. 1 The correlations between TOC and PC /UCS

\section{Chemical components measurements results}

Based on the same orthogonal experimental design for macroscopic tests, the S/S sludge TOC is measured for every sample. The correlations between TOC and PC/ UCS are shown in Fig.1. Since the initial TOC for samples are the same, the TOC value in Fig. 1 means the TOC residual. The smaller the TOC, the high the TOC consumption is. As shown in Fig.1, PC and UCS changes with TOC consumption correspondingly: PC decreases correspondingly when TOC consumption increases, UCS increases correspondingly when TOC consumption increases, which has verified that, the organic matter consumption extent represents the solidification effect of S/S sludge with high TOC. So, in order to figure out the influence factors of organic matter consumption, the chemical components measurements of $\mathrm{S} / \mathrm{S}$ sludge such as $p H, E C$ and $\mathrm{Ca}^{2+}$ concentration are analyzed together with TOC, based on the same orthogonal experimental design, as shown in Fig.2.

\section{$5.1 \mathrm{pH}$ analysis}

According to the $\mathrm{pH}$ shown in Fig. 2(a), the similar range analysis as the macroscopic tests is done, and the SLS on $\mathrm{pH}$ is: $T_{W c}>T_{C c}>T_{M c}>T_{L c}(1.67>0.9>0.83>0.61)$. This 

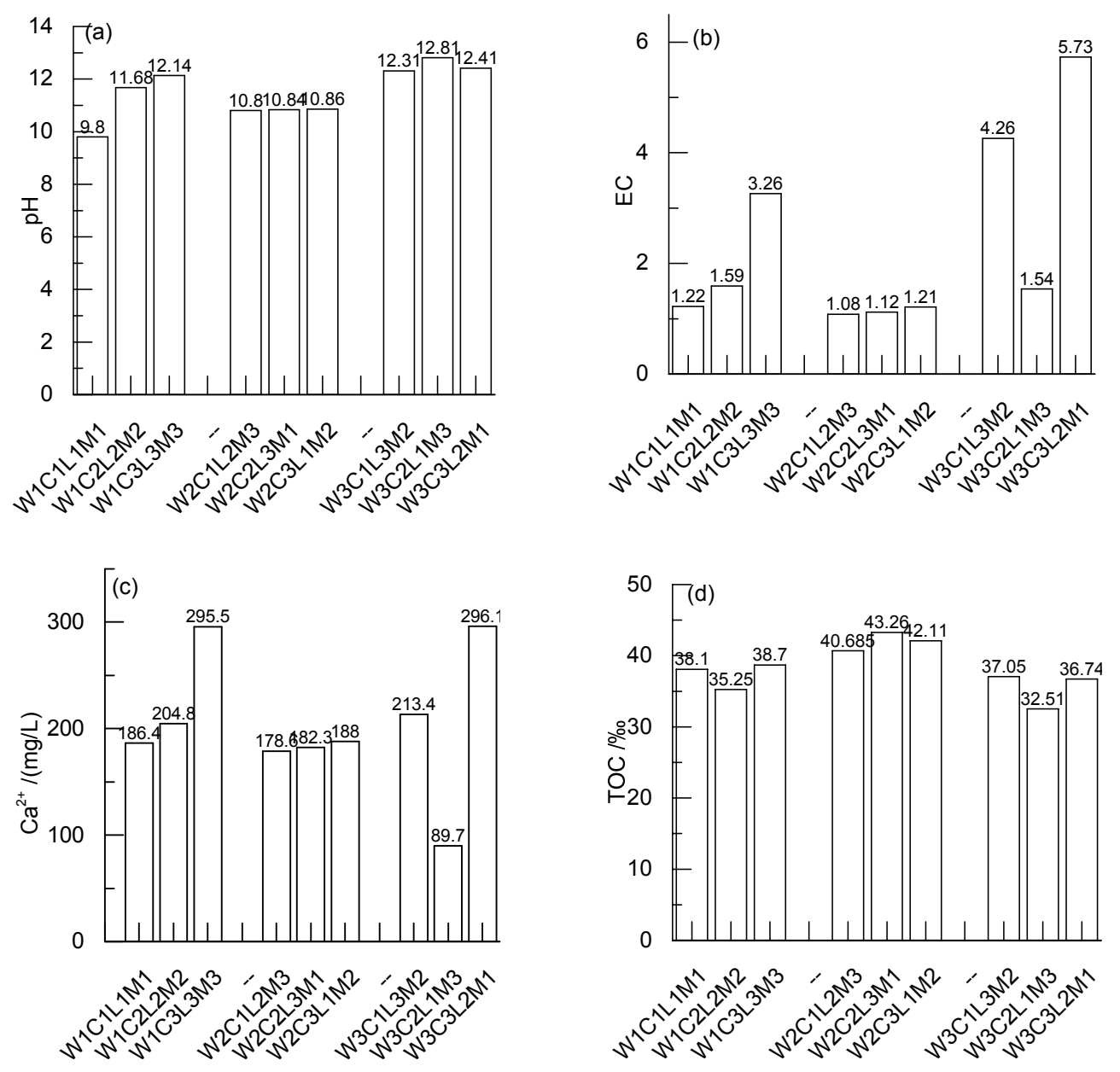

Fig. 2 Chemical components analysis: (a) pH distribution (b) EC distribution (c) $\mathrm{Ca}^{2+}$ concentration distribution (d) TOC distribution

indicates that $\mathrm{Wc}$ has the greatest influence on $\mathrm{pH}$. As shown in Fig. 2(a), when Wc is $120 \%$, S/S sludge $\mathrm{pH}$ is obviously higher than others'. In the solidification reaction by cement and other solidification agents, a large amount of water is needed to be consumed [28]. The higher the $\mathrm{pH}$, the better the alkaline environment in $\mathrm{S} / \mathrm{S}$ sludge is, and the more sufficient the solidification reaction conducts. From this point of view, with the increase of initial water content, the solidification effect will be optimized to some extent, which is different from the traditional compaction method. But it is also shown in Fig. 2(a) that, when Wc is $100 \%, \mathrm{~S} / \mathrm{S}$ sludge $\mathrm{pH}$ is lower than that with $\mathrm{Wc}$ of $80 \%$, indicating that there should be a critical value, around which the solidification effect is the worst.

\section{2 $\mathrm{EC}$ and $\mathrm{Ca}^{2+}$ concentrations analysis}

According to $\mathrm{EC}$ and $\mathrm{Ca}^{2+}$ concentrations shown in Fig. 2(b, c), the similar range analysis as the macroscopic tests is also done, and the SLS on EC and $\mathrm{Ca}^{2+}$ concentrations are gained. For $E C, T_{L c}>T_{C c}>T_{W c}>T_{M c}(3.891>3.104>2.706>0.73)$.
For $\mathrm{Ca}^{2+}$ concentration, $T_{L c}>T_{C c}>T_{W c}>T_{M c}(279.567>$ $237.733>45.933>33.667)$. Therefore, $L c$ has the greatest influence on $E C$ and $\mathrm{Ca}^{2+}$ concentrations. The results of Fig. $2(\mathrm{~b}, \mathrm{c})$ and the above range analysis show that, $\mathrm{EC}$ is closely related to $\mathrm{Ca}^{2+}$ concentration: $\mathrm{EC}$ increases when $\mathrm{Ca}^{2+}$ concentration increases, vice versa.

Since lime is rich in Calcium, $\mathrm{Ca}^{2+}$ concentration increases with the increase of lime content. However, it is shown in Fig. 2(b, c) that, EC of W1C3L3M3 are smaller than that of W3C3L3M1, because of the metakaolin content difference. Metakaolin can rapidly react with the hydration products of cement and lime to produce three-dimensional lattice structure colloid instead of soil particles, thus reducing the free $\mathrm{Ca}^{2+}$. Similarly, the addition of metakaolin in the sample $\mathrm{W} 3 \mathrm{C} 2 \mathrm{~L} 1 \mathrm{M} 3$ is the most, while the addition of lime is $0 \%$, the $\mathrm{Ca}^{2+}$ concentration is the minimum to be only 89.7. Therefore, the addition of lime will provide alkaline environment optimization for solidification reaction, so as to optimize the solidification effect. However, metakaolin also consumes $\mathrm{OH}^{-}$produced 
by lime, thereby reduces the promotion of lime to cement related reactions. Hence there should be a balance value between the metakaolin content and lime content, around which the solidification effect is the best.

\subsection{TOC analysis}

According to TOC shown in Fig. 2(d), the similar range analysis is done, and the SLS is: $T_{W c}>T_{C c}>T_{L c}>T_{M c}(6.59$ $>2.18>2.11>2.07$ ). Therefore, the initial water content has the greatest influence on TOC, and the SLS of TOC is similar to that of $\mathrm{pH}$. It is shown in Fig. 2(d) that, when $W_{c}$ is $120 \%$, the organic matter consumption is obviously higher than that of others-the residual TOC is lower. This is because, in sufficient water conditions, solidification agent can fully react to produce large amounts of $\mathrm{OH}^{-}$. Compared with $\mathrm{pH}$ changing rule in Fig. 2(a), it is shown that, the higher the $\mathrm{pH}$, the lower the TOC, which indicates that alkaline environment will greatly promote the organic matter consumption. Therefore, $W c$ will directly affect the organic matter consumption. In addition, based on the changing rules of $\mathrm{Ca}^{2+}$ concentrations and $E C$ shown in Fig. 2(b, c), the ratio between $M c$ and $L c$ will directly affect the $\mathrm{Ca}^{2+}$ concentration and $\mathrm{OH}^{-}$concentration in $\mathrm{S} / \mathrm{S}$ sludge, so it will also affect the organic matter consumption.

\section{Microscopic analysis results}

\subsection{Micro-morphology analysis}

As the internal structure shown in Fig.3, the S/S sludge is a mixture of solidification skeleton and soil aggregate: solidification skeleton is much larger in size, soil aggregate covered with solidification products are distributed among solidification skeleton. And the residue from animals or plants which will produce organic matter is caught in the SEM image.

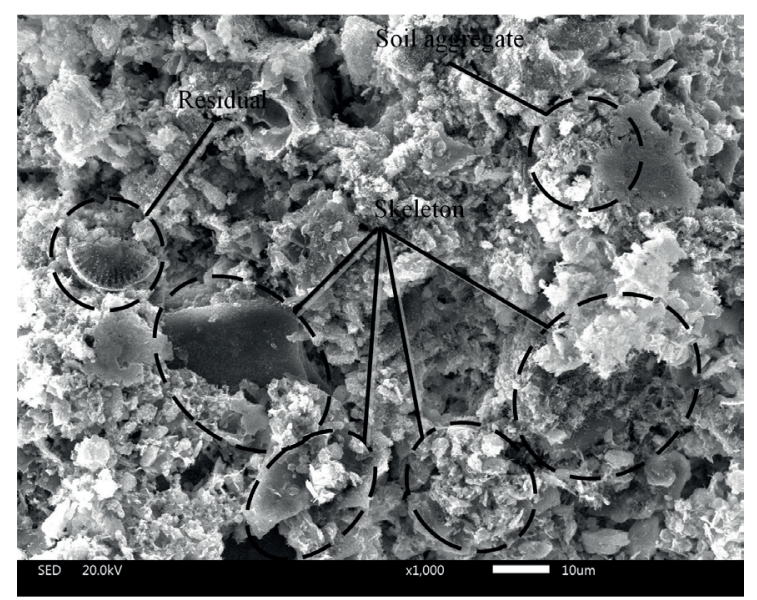

Fig. 3 The presence proof of organic matter in S/S sludge (2000 times)
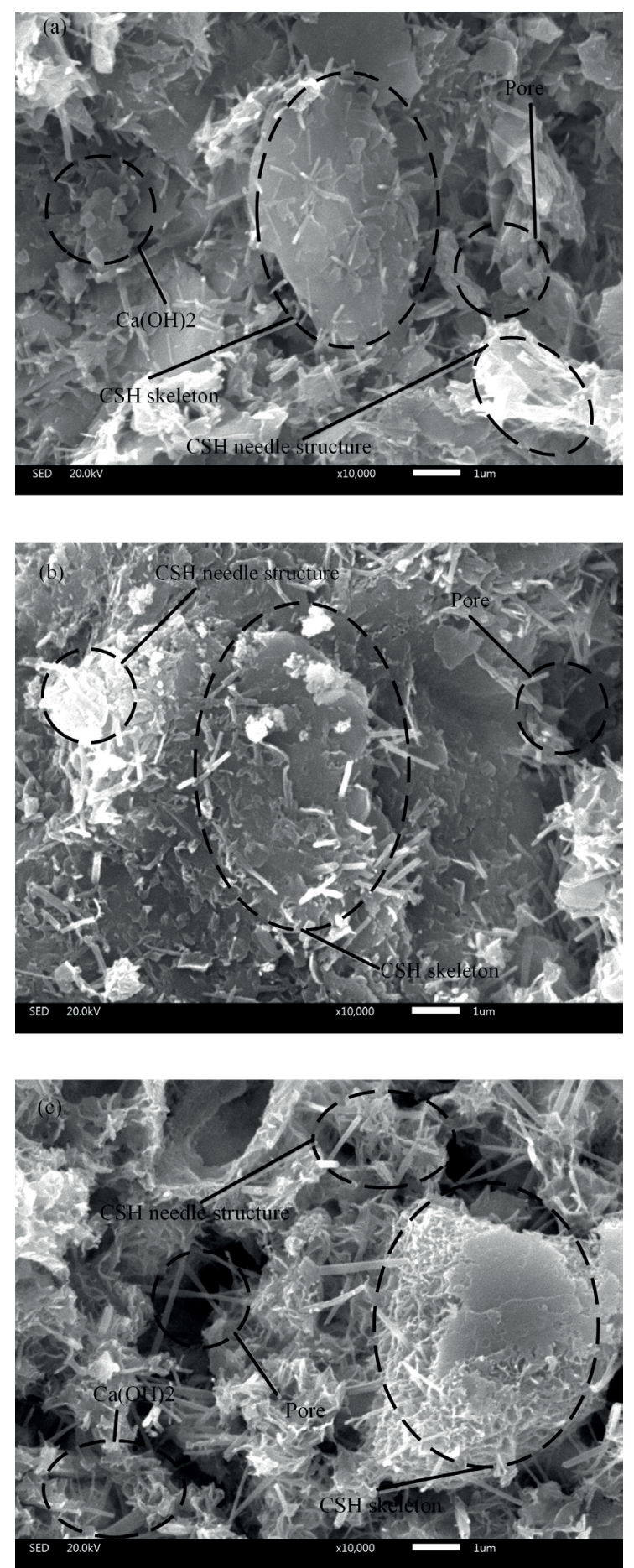

Fig. 4 Micro-morphology of S/S sludge (10,000 times): (a) W2C2L3M1, $C c=12 \% L c=3 \%, M c=0 \% ;$ (b) W2C3L1M $2, C c=15 \% L c=0 \%, M c$

$=1 \%$; (c) W2C1L2M $3, C c=10 \% L c=2 \%$ lime, $M c=2 \%$

In order to find out the microscopic structure of $\mathrm{S} / \mathrm{S}$ sludge, 3 representative samples for 10,000 times SEM analysis are selected, as shown in Fig. 4. It is shown in Fig. 4(a) that, when solidification agents are mainly cement and lime(W2C2L3M1), the S/S sludge internal structure mainly includes: Calcium Silicate Hydrate (CSH) colloidal 
skeleton developed from CSH colloid fluffy needle structure, produced by cement and lime solidification reactions, $\mathrm{Ca}(\mathrm{OH})_{2}$ crystal bulky flaky structure by lime hydration reaction, and randomly distributed pores. It is shown in Fig. 4(b) that, when solidification agents are mainly cement and metakaolin(W2C3L1M2), the CSH colloidal solidified skeleton inside is larger in size and amount, the CSH colloidal fluffy needle structure is also distributed, and all $\mathrm{Ca}(\mathrm{OH})_{2}$ crystal bulky flaky structures disappeared due to lack of lime, the pores are more compacted. It is shown in Fig. 4(c) that, when cement, lime and metakaolin added simultaneously (W2C1L2M3), CSH colloidal fluffy needle structure is more auxetic, $\mathrm{Ca}(\mathrm{OH})_{2}$ crystal fluffy sheet structure is more than W2C3L1M2 because of lime addition, and less than W2C2L3M1 since metekaolin will consume parts of $\mathrm{Ca}(\mathrm{OH})_{2}$ to produce $\mathrm{CSH}$, and the pores are looser compared with W2C2L3M1. To sum up, lime will consume organic matter so as to promote the solidification reactions, but excess lime produce weak $\mathrm{Ca}(\mathrm{OH})_{2}$ crystal bulky flaky structures. Metakaolin produce rapid reactions with $\mathrm{Ca}(\mathrm{OH})_{2}$ to consume excess lime and promote the sufficient solidification of cement, but excess metakaolin will induce the solidification skeleton to be looser.

\subsection{Microscopic pore structure analysis}

The pore areas for the above three samples are exacted for quantitative analysis by the SEM images binarization, as shown in Fig.5. As shown in Fig.5, the total pore area of W2C2L3M1 is the largest of $21324 \mu \mathrm{m}^{2}$, due to a large amount of pores produced among the $\mathrm{Ca}(\mathrm{OH})_{2}$ crystal bulky flaky structures because of lime addition. The total pore area of $\mathrm{W} 2 \mathrm{C} 3 \mathrm{~L} 1 \mathrm{M} 2$ is the smallest of $5594 \mu \mathrm{m}^{2}$, due to the $\mathrm{Ca}(\mathrm{OH})_{2}$ crystal bulky flaky structures vanishing because of lime absence. The total pore area of W2C1L2M3 is $9343.629 \mu \mathrm{m}^{2}$, which is bigger than W2C3L1M2 due to the CSH colloidal fluffy needle structure increase, and smaller than $\mathrm{W} 2 \mathrm{C} 2 \mathrm{~L} 3 \mathrm{M} 1$ due to the $\mathrm{Ca}(\mathrm{OH})_{2}$ crystal bulky flaky structures decrease.

At the same time, the comparison analysis of the $\mathrm{S} / \mathrm{S}$ slit internal pore area with the PC and UCS is executed as shown in Fig.5. It is shown that, PC and UCS are closely related to the internal pore area: the greater the pore area the greater the $\mathrm{PC}$ is, the larger the pore area the smaller the UCS is. In a case study of W2C2L3M1, Ca(OH $)_{2}$ crystal bulky flaky structures is produced since Lc is high, so despite of the organic matter consumption by lime addition, the solidification is the worst, the pore area is the

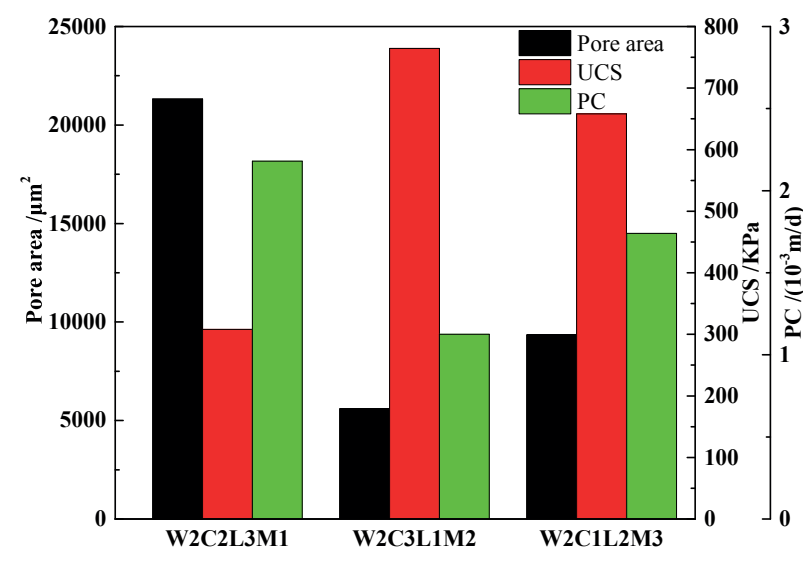

Fig. 5 Pore area, UCS and PC distributions of S/S sludge

biggest, $\mathrm{PC}$ is the biggest, and UCS is the smallest. In a case study of W2C3L1M2, under the promotion of metakaolin, the cement can fully react to form the complete CSH colloid skeleton due to the sufficiency of $\mathrm{Cc}$ and $\mathrm{Mc}$, so the solidification effect is the best, the pore area is smallest, PC is the smallest, and UCS is the biggest. In a case study of W2C1L2M3, when metakaolin and lime added simultaneously, on one hand metakaolin will promoted cement solidification reaction, on the other hand metakaolin will promote the consumption of $\mathrm{Ca}(\mathrm{OH})_{2}$ crystal bulky flaky structure produced by excess lime addition, so the solidification effect is improved compared with sample W2C2L3M1, even though less cement is added.

\section{Conclusions}

In order to confirm the key controlling technique points for high organic matter content sludge solidification, macroscopic test such as permeability coefficient (PC) test and unconfined compression strength (UCS) test, chemical components measurements for $\mathrm{pH}$ value, electrical conductivity (EC), $\mathrm{Ca}^{2+}$ concentration and organic matter content (TOC), and microscopic analysis such as SEM are conducted for $\mathrm{S} / \mathrm{S}$ sludge based on orthogonal test program. And the following conclusions are obtained.

1. The S/S sludge PC is mainly affected by lime content and initial moisture, while its UCS is mainly affected by cement content and lime content.

2. The $\mathrm{S} / \mathrm{S}$ sludge solidification effect is positively related to the organic matter consumption: the higher the consumption, the better the solidification effect is.

3. The $\mathrm{S} / \mathrm{S}$ sludge organic matter consumption is positively related to $\mathrm{pH}$, and determined by the alkaline environment from cement and lime hydration reactions. 
4. The $\mathrm{pH}$ value is mainly determined by the initial moisture, around which there is a critical value where the $\mathrm{pH}$ is the smallest. And the alkaline environment is also affected by the ratio of metakaolin content and lime content, around which there is a balance value where the alkaline environment is the best.

5. Lime addition in $\mathrm{S} / \mathrm{S}$ sludge promotes organic matter consumption by neutralization reaction, however, excess lime addition produces weak $\mathrm{Ca}(\mathrm{OH})_{2}$ crystal bulky flaky structure. The metakaolin addition in $\mathrm{S} / \mathrm{S}$ sludge promotes the rapid pozzolanic reaction with $\mathrm{Ca}(\mathrm{OH})_{2}$ to enhance the solidification effect, but excess metakaolin addition will consume the lime addition needed for organic matter consumption.

\section{Acknowledgement}

This research is financially supported by National Natural Science of China (Grant No. 51709154), Hubei Provincial Natural Science Foundation of China (Grant No. 2016CFB237), and Open Project Fund of Tianjin Key Laboratory of Soft Soil Characteristic and Engineering Environment, Tianjin Chengjian University of China (Grant No. KJ2016QT011).

\section{References}

[1] Xu, Y., Zhang, C., Zhao, M., Rong, H., Zhang, K., Chen, Q. "Comparison of bioleaching and electrokinetic remediation processes for removal of heavy metals from wastewater treatment sludge", Chemosphere, 168, pp. 1152-1157, 2017.

https://doi.org/10.1016/j.chemosphere.2016.10.086

[2] Mymrin, V., Stella, J. C., Scremim, C. B., Pan, R. C. Y., Sanches, F. G., Alekseev, K., Pedroso, D. E., Molinetti, A., Fortini, O. M. "Utilization of sediments dredged from marine ports as a principal component of composite material", Journal of Cleaner Production, 142(4), pp. 4041-4049, 2017.

https://doi.org/10.1016/j.jclepro.2016.10.035

[3] Wang, L., Tsang, D. C. W., Poon, C. S. "Green remediation and recycling of contaminated sediment by waste-incorporated stabilization/solidification", Chemosphere, 122, pp. 257-264, 2015.

https://doi.org/10.1016/j.chemosphere.2014.11.071

[4] Messina, F., Ferone, C., Molino, A., Roviello, G., Colangelo, F., Molino, B., Cioffi, R. "Synergistic recycling of calcined clayey sediments and water potabilization sludge as geopolymer precursors: Upscaling from binders to precast paving cement-free bricks", Construction and Building Materials, 133, pp. 14-26, 2017. https://doi.org/10.1016/j.conbuildmat.2016.12.039

[5] Peng, X., Zhou, Y., Jia, R., Wang, W., Wu, Y. "Preparation of non-sintered lightweight aggregates from dredged sediments and modification of their properties", Construction and Building Materials, 132, pp. 9-20, 2017.

https://doi.org/10.1016/j.conbuildmat.2016.11.088
[6] Wang, T., Xue, Y., Zhou, M., Yuan, Y., Zhao, S., Tan, G., Zhou, X., Geng, J., Wu, S., Hou, H. "Comparative study on the mobility and speciation of heavy metals in ashes from co-combustion of sewage sludge/dredged sludge and rice husk", Chemosphere, 169, pp. 162-170, 2017.

https://doi.org/10.1016/j.chemosphere.2016.11.070

[7] Dabo, D., Badreddine, R., De Windt, L., Drouadaine, I. "Ten-year chemical evolution of leachate and municipal solid waste incineration bottom ash used in a test road site", Journal of Hazardous Materials, 172(2-3), pp. 904-913, 2009.

https://doi.org/10.1016/j.jhazmat.2009.07.083

[8] Pan, K., Wang, W.-X. "Trace metal contamination in estuarine and coastal environments in China", Science of The Total Environment, 421-422, pp. 3-16, 2012.

https://doi.org/10.1016/j.scitotenv.2011.03.013

[9] Müller, U., Rübner, K. "The microstructure of concrete made with municipal waste incinerator bottom ash as an aggregate component", Cement and Concrete Research, 36(8), pp. 1434-1443, 2006. https://doi.org/10.1016/j.cemconres.2006.03.023

[10] Kunal, Siddique, R., Rajor, A. "Strength and microstructure analysis of bacterial treated cement kiln dust mortar", Construction and Building Materials, 63, pp. 49-55, 2014. https://doi.org/10.1016/j.conbuildmat.2014.04.011

[11] Ahmed, A. "Compressive strength and microstructure of soft clay soil stabilized with recycled bassanite", Applied Clay Science, 104, pp. $27-35,2015$.

https://doi.org/10.1016/j.clay.2014.11.031

[12] Zentar, R., Abriak, N.-E., Dubois, V. "Effects of salts and organic matter on Atterberg limits of dredged marine sediments", Applied Clay Science, 42(3-4), pp. 391-397, 2009. https://doi.org/10.1016/j.clay.2008.04.003

[13] Hansen, M., Bang-Andreasen, T., Sørensen, H., Ingerslev, M. "Micro vertical changes in soil $\mathrm{pH}$ and base cations over time after application of wood ash on forest soil", Forest Ecology and Management, 406, pp. 274-280, 2017.

https://doi.org/10.1016/j.foreco.2017.09.069

[14] Ke, Y., Ning, X., Liang, J., Zou, H., Sun, J., Cai, H., Lin, M., Li, R., Zhang, Y. "Sludge treatment by integrated ultrasound-Fenton process: Characterization of sludge organic matter and its impact on PAHs removal" Journal of Hazardous Materials, 343, pp. 191-199, 2018.

https://doi.org/10.1016/j.jhazmat.2017.09.030

[15] Zhong, H.-Y., Wang, H., Liu, X., Liu, C., Liu, G.-Y., Tian, Y., Feng, X., Chen, Y. H. "Degradation and characteristic changes of organic matter in sewage sludge using Vermi-biofilter system", Chemosphere, 180, pp. 57-64, 2017. https://doi.org/10.1016/j.chemosphere.2017.03.121

[16] Liu, H. "Relationship between organic matter humification and bioavailability of sludge-borne copper and cadmium during longterm sludge amendment to soil", Science of the Total Environment, 566-567, pp. 8-14, 2016. https://doi.org/10.1016/j.scitotenv.2016.05.023

[17] Shahbaz, M., Kuzyakov, Y., Heitkamp, F. "Decrease of soil organic matter stabilization with increasing inputs: Mechanisms and controls", Geoderma, 304, pp. 76-82, 2017. https://doi.org/10.1016/j.geoderma.2016.05.019 
[18] Tadini, A. M., Nicolodelli, G., Senesi, G. S., Ishida, D. A., Montes, C. R., Lucas, Y., Mounier, S., Guimarães, F. E. G., Milori, D. M. B. P. "Soil organic matter in podzol horizons of the Amazon region: Humification, recalcitrance, and dating", Science of the Total Environment, 613-614, pp. 160-167. 2018. https://doi.org/10.1016/j.scitotenv.2017.09.068

[19] Frouz, J. "Effects of soil macro- and mesofauna on litter decomposition and soil organic matter stabilization", Geoderma, 332, pp. 161-172, 2018.

https://doi.org/10.1016/j.geoderma.2017.08.039

[20] Du, Y. J., Wei, M. L., Reddy, K. R., Liu, Z. P., Jin, F. "Effect of acid rain $\mathrm{pH}$ on leaching behavior of cement stabilized lead-contaminated soil", Journal of Hazardous Materials, 271, pp. 131-140, 2014.

https://doi.org/10.1016/j.jhazmat.2014.02.002

[21] Ahmed, A., Issa, U. H. "Stability of soft clay soil stabilised with recycled gypsum in a wet environment", Soils and Foundations, 54(3), pp. 405-416, 2014.

https://doi.org/10.1016/j.sandf.2014.04.009

[22] Saride, S., Puppala, A. J., Chikyala, S. R. "Swell-shrink and strength behaviors of lime and cement stabilized expansive organic clays", Applied Clay Science, 85, pp. 39-45, 2013. https://doi.org/10.1016/j.clay.2013.09.008

[23] Sariosseiri, F., Muhunthan, B. "Effect of cement treatment on geotechnical properties of some Washington State soils", Engineering Geology, 104(1-2), pp. 119-125, 2009. https://doi.org/10.1016/j.enggeo.2008.09.003

[24] Navarro-Blasco, I., Duran, A., Sirera, R., Fernández, J. M., Alvarez, J. I. "Solidification/stabilization of toxic metals in calcium aluminate cement matrices", Journal of Hazardous Materials, 260, pp. 89-103, 2013.

https://doi.org/10.1016/j.jhazmat.2013.04.048

[25] Gollmann, M. A. C., da Silva, M. M., Masuero, Â. B., dos Santos, J. H. Z. "Stabilization and solidification of $\mathrm{Pb}$ in cement matrices", Journal of Hazardous Materials, 179(1-3), pp. 507-514, 2010. https://doi.org/10.1016/j.jhazmat.2010.03.032

[26] Harichane, K., Ghrici, M., Kenai, S. "Stabilization of algerian clayey soils with natural pozzolana and lime", Periodica Polytechnica Civil Engineering, 62(1), pp. 1-10, 2018. https://doi.org/10.3311/PPci.9229

[27] Bell, F. G. "Lime stabilization of clay minerals and soils", Engineering Geology, 42(4), pp. 223-237, 1996. https://doi.org/10.1016/0013-7952(96)00028-2

[28] Jauberthie, R., Rendell, F., Rangeard, D., Molez, L. "Stabilisation of estuarine silt with lime and/or cement", Applied Clay Science, 50(3), pp. 395-400, 2010. https://doi.org/10.1016/j.clay.2010.09.004

[29] Osula, D. O. A. "A comparative evaluation of cement and lime modification of laterite", Engineering Geology, 42(1), pp. 71-81, 1996.

https://doi.org/10.1016/0013-7952(95)00067-4

[30] Wang, D., Abriak, N. E., Zentar, R. "Strength and deformation properties of Dunkirk marine sediments solidified with cement, lime and fly ash", Engineering Geology, 166, pp. 90-99, 2013. https://doi.org/10.1016/j.enggeo.2013.09.007
[31] Lemaire, K., Deneele, D., Bonnet, S., Legret, M. "Effects of lime and cement treatment on the physicochemical, microstructural and mechanical characteristics of a plastic silt", Engineering Geology, 166, pp. 255-261, 2013.

https://doi.org/10.1016/j.enggeo.2013.09.012

[32] Xu, W., Xu, J., Liu, J., Li, H., Cao, B., Huang, X., Li, G. "The utilization of lime-dried sludge as resource for producing cement", Journal of Cleaner Production, 83, pp. 286-293, 2014.

https://doi.org/10.1016/j.jclepro.2014.07.070

[33] Kolovos, K. G., Asteris, P. G., Cotsovos, D. M., Badogiannis, E., Tsivilis, S. "Mechanical properties of soilcrete mixtures modified with metakaolin", Construction and Building Materials, 47, pp. 1026-1036, 2013. https://doi.org/10.1016/J.CONBUILDMAT.2013.06.008

[34] Stefanidou, M., Tsardaka, E.-C., Pavlidou, E. "Influence of nano-silica and nano-alumina in lime-pozzolan and lime-metakaolin binders", Materials Today: Proceedings, 4(7), pp. 6908-6922, 2017.

https://doi.org/10.1016/J.MATPR.2017.07.020

[35] Asteris, P. G., Kolovos, K. G. "Data on the physical and mechanical properties of soilcrete materials modified with metakaolin", Data in Brief, 13, pp. 487-497, 2017. https://doi.org/10.1016/J.DIB.2017.06.014

[36] Wu, Z., Deng, Y., Liu, S., Liu, Q., Chen, Y., Zha, F. "Strength and micro-structure evolution of compacted soils modified by admixtures of cement and metakaolin", Applied Clay Science, 127-128, pp. 44-51, 2016. https://doi.org/10.1016/J.CLAY.2016.03.040

[37] Xia, S., Lin, R., Cui, X., Shan, J. "The application of orthogonal test method in the parameters optimization of PEMFC under steady working condition", International Journal of Hydrogen Energy, 41(26), pp. 11380-11390, 2016.

https://doi.org/10.1016/j.ijhydene.2016.04.140

[38] Zou, G., Xu, J., Wu, C. "Evaluation of factors that affect rutting resistance of asphalt mixes by orthogonal experiment design", International Journal of Pavement Research and Technology, 10(3), pp. 282-288, 2017. https://doi.org/10.1016/j.ijprt.2017.03.008

[39] Großmann, H. "Automating the analysis of variance of orthogonal designs", Computational Statistics and Data Analysis, 70, pp. 1-18, 2014.

https://doi.org/10.1016/j.csda.2013.08.014

[40] Ho, W. K., Chen, T., Ling, K. V., Sun, L. "Variance analysis of robust state estimation in power system using influence function", International Journal of Electrical Power \& Energy Systems, 92, pp. 53-62, 2017.

https://doi.org/10.1016/j.ijepes.2017.04.009 